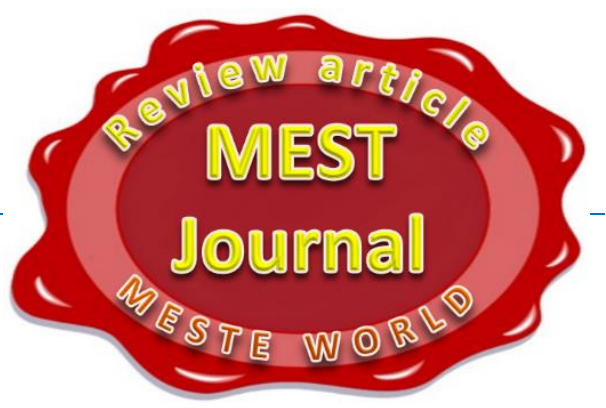

\title{
MANAGING RENEWABLE ENERGY PROJECTS INCLUDING RISK ANALYSIS
}

\section{Natalija Petrova}

Ss. Cyril and Methodius University, Faculty of Electrical Engineering and Information Technologies, Skopje, Macedonia

\section{Nevenka Kiteva Rogleva}

Ss. Cyril and Methodius University, Faculty of Electrical Engineering and Information Technologies, Skopje, Macedonia

\section{Vangel Fustik}

Ss. Cyril and Methodius University, Faculty of Electrical Engineering and Information Technologies, Skopje, Macedonia

OMESTE

JEL Category: D81, Q2, Q42

\begin{abstract}
The paper makes deep insight into project management and risk analysis of renewable energy sources (RES). This approach could be very helpful in the organizational and managerial approach for project success and investments in RES projects. The intent of the paper is to focus primarily on project management techniques for the purpose of achieving project's objectives and second on tools for risk assessment of renewable energy projects in order to define and evaluate risks so that they can be adequately mitigated to attract future investment. Particular energy sources - elevated hydropower used in small hydropower plants, and photovoltaic plants are considered in Section 3, as case studies, to identify and explore risk management approach for planning risk response during project implementation. Section 3.1 provides an overview of the major identified risks which include financial, political and operational risks, risks related to human resources and risks associated with renewable energy developments and markets. Discussion and conclusion are presented at the end of the article.
\end{abstract}

Keywords: Risk management, Renewable energy, Project implementation

\section{INTRODUCTION}

The new economy of 21 century and new project environment provoke a need for changes in the

The address of the corresponding author: Petrova-Natalija

莑=゙ natalija.petrova11@yahoo.com organizational structure and management approaches, skills and tools. The new and undertaken EU policies in the framework of climate changes stimulate the electricity generation from renewable energy resources (REN21, 2017). The possibilities, number, and diversity of such projects depend on the investor's 
expected project success that will ensure a projected profit margin. Since those projects could be very specific depending on a particular energy source and that there is a lack of needed experience in their implementation, managers need to be well educated in risk management and aware of possible known and unknown risks to be planed and treated during project implementation.

Renewable energy projects are projects that include a construction of photovoltaic power system (PVS), small hydroelectric power plant (SHPP), wind power plant (WPP), biogas or biomass thermal power plant etc. Each of them, as a unique and complex project, is a special challenge for energy development and it has certain uncertainties and risks.

According to (Michelez, et al., 2011), a key challenge in obtaining financing at a reasonable cost is the ability to quantify and manage the different elements of risk (i.e. organizational, political, technical, commercial) associated with RES projects. Un-renewable energy projects have been developing methodologies for risk assessment for many years. Using the lessons learned in detail can be understood, what is transferable to RES projects.

\section{PROJECT RISK MANAGEMENT}

Project risk can be defined as:

- the cumulative effect of the chances of uncertain events that negatively affect the project objectives;

- or degree of exposure to negative events and their possible consequences (positive events) affecting the project objectives expressed through the scope, quality, costs and time.

In modern understandings and risk education, the risk is considered to be accompanied by the possibility that may arise from the estimated/ predicted risk. This means, when some risk appears in the event, it can be redirected to an opportunity with a little inventiveness and prediction (REN21, 2017).

The objectives of Project Risk Management are to increase the probability and impact of positive events and decrease the probability and impact of negative events in the project.
Risk Management Process consists of five phases: planning, identification, analysis, risk response, monitoring and controlling identified risks. According to (PMI, 2010), risk management planning is defined as a decision-making process on how to approach, plan, and how to implement the risk management activities of an appropriate project. Identification is a process that consists of identifying and determining which risks can affect the confidentiality of an object and document their characteristics. Risk analysis includes a quantitative and qualitative assessment. The response to the risks is the process of developing options and defining actions for improving the opportunities and reducing the losses of the project objectives. Monitor and control risks are the processes of identifying, analyzing and planning new existing risks and monitoring the identified risks.

\subsection{Types of Project Risk}

There are several types of risks that are considered during the identification phase: Financial risk such as investment, financing, profit, etc.; Risks from a legal aspect (Legal risk) such as procedures, laws, alterations and restrictions; Natural and physical risks; Risks related to human resources, knowledge, various relationships between stakeholders; Technical risks; Security risks, etc.

Disassembled risk structure (Risk breakdown structure) is used to divide the project into components such as organizational, financial and technical aspects, external factors and project management. Usually, the financial aspects are devoted the most attention and are well designed, giving the guidelines for consistent management based on the predicted cash flow (Tonchia, 2008) (Wallnerstrom, 2009). So, the analysis of these risks can be included in the general risk package given in the commissioned work prepared by the project team.

Technical risks often reach a high level of specificity as they are affected by the equipment or characteristics of the plant that uses RES and must be well studied by experts and companies that have the specific expertise needed to quantify and accurately represent. These risks have an economic impact on the budget of the commissioned work. Technical risks can be 
different and numerous and primarily relate to equipment and plants, and as such (although often with an increased risk of, for example, unproven in practice technologies) are internal risks of the companies and are controllable by the project management (Wallnerstrom, 2009).

External risk factors are caused by external conditions: market economy, politics, etc. and as such are non-controllable. These include socioeconomic risks.

Known risks are those that have already been identified and analyzed and management can plan a solution and future efforts to eliminate the consequences of the errors.

The unknown risks cannot be managed proactively and as a response from the management team, might be allocating general conditionality against such risks, as well as against any known risks that may not be worthwhile or cannot develop a proactive response.

Certain individuals have their own views on the risk and courage to accept and deal with it. Attitudes about risk (or risk views) should be explicit wherever possible. Risk responses reflect the organizational balance between taking and avoiding risk. To be a successful project, the project organization must be committed to addressing risk management proactively and consistently through the process.

\subsection{Risks in Project Life Cycle}

A project life cycle is a collection of generally sequential and overlapping project phases. The number of phases is determined by:

- the management and control need of the stakeholders involved in the projects;

- $\quad$ the nature of the project itself;

- and its area of application.

Every project is unique because it has a definite start and a definite end, and definite scope of works. The deliverables and activities that take place in between will vary widely with the project. The project life cycle provides the basic framework for managing the specific work.

According to project size and complexity, the project manager may determine the need for more effective planning and control over certain activities and deliverables. Large and complex projects, in particular, may require this additional level of control. In such instances, the work carried out to complete the project's objective may benefit from being formally divided into phases.

Every project is composed of 4 phases: concept, development, implementation, and completion of the project, which are specific to each project. The first two phases constitute the planning of the project, while the second two are an integral part of the implementation of the project itself (fig.1) (Wideman, 1992).

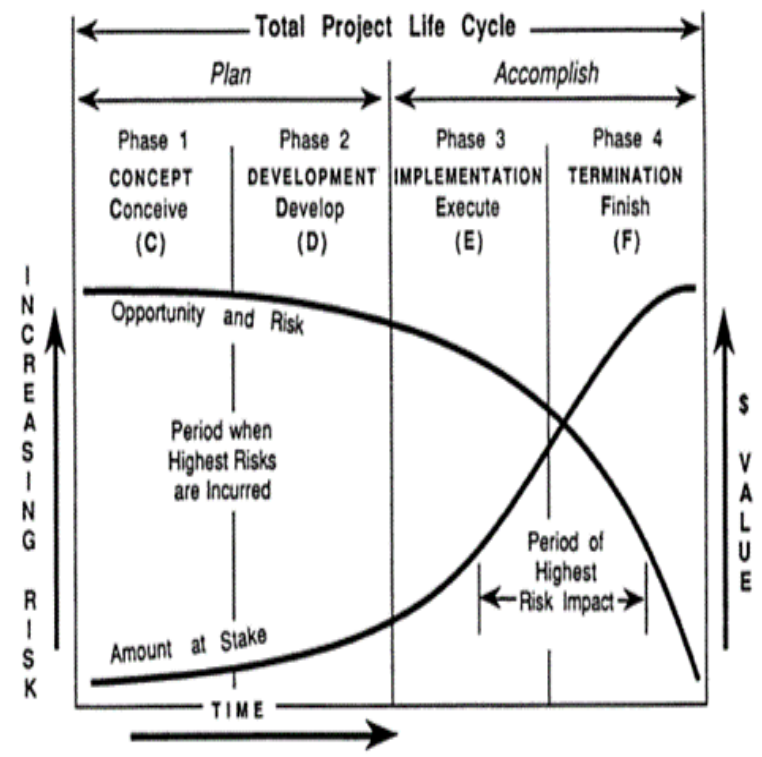

Fig.1. Total Project Life Cycle (Wideman, 1992)

It is important to note that the opportunity and risk remain relatively high during planning, but due to the relatively low level of investment in that period, the amount invested remains small. Contrary to that, during the realization of the project and the opportunity and risk gradually decrease to lower levels because the risk can already be predicted. At the same time, the amount invested is constantly increasing by investing in the necessary resources to complete the project.

This is graphically shown in fig. 1. The figure also shows that the period of highest risk impact occurs during the last two phases. At that point, unfavorable conditions can also be detected as a result of acceptance testing and putting into operation of the project. The purpose of risk management is to influence the planning of the project so that the uncertainty-risk and the amount of stake are reduced to acceptable levels throughout the life cycle of the project. 


\subsection{Techniques for identification, evaluations and risk control in RES}

\subsubsection{Risk Identification}

The project manager, project team leaders, project team, risk management team if set, outside experts, customers, end users, and external risk management experts are those who can do the risk identification phase. This phase of identifying all possible risks is an iterative process that involves new detective risks by the progression of the process throughout its life cycle (Kendrick, 2003) (Rausand, 2004).

The most commonly used risk identification techniques are (Michelez, et al., 2011):

- Brainstorming is a method of collecting all stakeholders - experts in order to generate and classify ideas of potential project risk.

- Interviewing experts and asking them questions to which they give their answers.

- Cause-effect diagrams are diagrams that analyze the root of the risk that the strategy for control should react.

In the simplest RES projects, for risk identification most often is used brainstorming. But, if projects became more complex, in that case, is preferred to use the others two techniques. Also, the Delphi method, as a structured approach for adopting a view of a range of experts on a specific issue, is recommended and used in cases, when there is a lack of historical data.

\subsubsection{Risk assessment}

The risk assessment consists of its qualitative and quantitative valuation. The impact is determined (Impact - I), and then probability (Probability - P) for each risk.

Qualitative risk analysis is the process of prioritizing risks for further analysis by assessing and combining their probability of occurrence and impact. The execution of a qualitative risk analysis is usually a quick and cost-effective means of determining the priorities of the risk response plan and sets the basis for carrying out a quantitative risk analysis, if necessary.

Quantitative risk analysis is a process of numerically analyzing the effects of the identified risks on the overall project objectives. Through quantitative risk analysis is expected to get some numerical results to express the probability of each risk factor and its impact on project objectives, but also the risk of the overall project level.

Risk assessment can be conducted through a management team discussion on each topic. But, if the projects are complex, the application of analysis tools is necessary. Different stakeholders will differ in their assessment of risk. These uncertainties can be combined in Monte Carlo based simulations resulting in the production of a probability function of budget, timeline, and profitability of the project.

The decision-making process of the management will depend on the severity of the problem $S=f(P, I)$ and the acceptability of the risks.

Table 1. Categories of the probability of occurrence and impact of a risk event

\begin{tabular}{|l|l|l|}
\hline & $\begin{array}{c}\text { Probability } \\
\text { of } \\
\text { occurrence }\end{array}$ & \multicolumn{1}{|c|}{ Impact } \\
\hline High (H) & $>70 \%$ & $\begin{array}{l}\text { can greatly } \\
\text { endanger } \\
\text { project } \\
\text { parameters }\end{array}$ \\
\hline Medium (M) & $\begin{array}{l}\text { between } 30 \\
\text { and } 70 \%\end{array}$ & $\begin{array}{l}\text { can affect with } \\
\text { middle size }\end{array}$ \\
\hline Low (L) & $<30 \%$ & $\begin{array}{l}\text { relatively low } \\
\text { impact }\end{array}$ \\
\hline
\end{tabular}

The most used term for risk assessment or Risk event status (RES) is:

$$
\begin{gathered}
\text { Risk }(\$ / \text { year })=\text { Impact }(\$) \times \text { Frequency of } \\
\text { occurrence }(1 / \text { year }) .
\end{gathered}
$$

Table1 allows us to perform prioritization of risks in preparing the plan in response to such risks. The probability of occurrence of a certain event and the impact of each event on the design parameters can be estimated in three (or more) categories (PMI, 2010).

Based on this categorization (table 1) risks matrix is filled (fig.2). Then the margin of dealing with potential risks is determined. The risks marked with red color are those that require response and handling as they would not endanger the project and its success, according to predefined criteria. 
The risk analysis is then followed by a formal corporate control procedure which places a requirement for the analysis on the project promoter and allocates responsibility for action. In practice, this can be conducted through the sequential project stages (e.g. Appraise-SelectDefine-Execute-Operate) with an incremental amount of investment/risk in each subsequent phase. The management strategy for each risk normally includes: a risk management plan (e.g. specific objectives, resources, timeline, accountability and reporting indicators, and frequency) and allocation of contingency budget to the project execution through the measurement P50-P80 values in probability functions.

Risk feedback - At the end of a given project, the project risk plan is compared to the actual project plan and results.

Key sources of risk and risk response for RES projects are:

- Political risks (often characterized by discrete events and therefore hard to control), country credit default swaps, risk sharing schemes, and insurance are important;

- Economic risks can be managed through mechanisms such as JVs and other arrangements, including insurance, guarantees, derivatives, and risk transfer approaches;

- Social risks can be captured as part of health safety, social and environmental impact assessments and stakeholder engagement plans. Specific mitigation measures are then developed by subject matter experts into a Health, Safety, Social and Environment (HSSE) management plan.

- Technical risks can be managed through guarantees, warranties, insurance, as well as agreements or other organizational arrangements between key parties. Therefore, there is significant overlap with measures to address economic risks.

The project team also identifies a number of general opportunities to develop and refine the methodology further, to engage key players on the methodology and to capture information on key risks associated with renewable energy (ensuring critical lessons are learned).
A number of recommendations organized by the stakeholder group are:

- The public sector should encourage the further development of the methodologies to support its important role in promoting or developing key support measures.

- Developers can benefit from this systematic approach to risk management; they can also benefit from linking this approach to measures to manage project risk.

- Investors can use this methodology to promote and develop support measures.

While many of the techniques and approaches will not be new to banks and others, there is a real need for key players to speak the same language. Once this has been achieved, it is possible to have a meaningful debate on what risks to accept, avoid or transfer. Finally, the approach will allow key players to have a realistic understanding of the risks involved in renewable energy technologies and develop appropriate support measures.

At the same time the development of a structured and rigorous approach to risk assessment and management will allow parties, such as smaller project promoters to engage effectively with less likely to be overlooked; the use of probabilistic modeling allows a discussion of uncertainty without creating a "black box" where the workings of the underlying model are not visible.

\section{CASE STUDIES}

The first phase of the research implemented in RES projects starts with project scope analyses and risk identification. This phase involves the collection of project documentation; analyses of project goals and scope of works. Risk identification starts by identifying all the potential risk associated with the project's objectives. We use a Delphi method as a most appropriate technique. Project teams, project managers, engineers and other stakeholders involved in the design and construction process, as well as external experts on risk management, have been interviewed. Their experiences in dealing with risks, and work on complex and multidisciplinary projects have been considered.

Main risks identified in the study, during the design and construction phase of a new SHPP and PV plant are presented below: 
1. The lack of policy knowledge or the procedure for obtaining a construction permits (number of permits and legislation). If terms and construction conditions are clearly defined to investors in advance, to develop renewable energy projects, investors will be able to reach a final decision based on the existing conditions;

2. Political involvement in permits obtaining;

3. Inappropriate obligation and penalty. This kind of problems creates a dilemma for the project developers (Wing \& Jin, 2015);

4. Connection permit from the Distribution Network Operator (DNO). An additional risk associated with DNO is net metering or unfair network conditions, such as high connection fee and high standby charge;

5. Insufficient addressing of the developer in the problems of network connection. Low connection rate and low dispatch priority further reduce the completeness of renewable energy projects. The point of connection to the transmission line and the variants of solutions too often can be so unfavorable that they can bring the RES project in question;

6. Inadequate exploration of water potential or unrealistic data can lead to wrong technical characteristics of the equipment designed for SHPP. The amounts of energy generation from SHPP are often unpredictable and it can cause substantial risk to investors (Swider, et al., 2008);

7. Financial risks. Project investor may face financial and practical issues, such as insufficient funding to achieve the project's targets. This kind of risk/uncertainty results in low-cost renewable energy technologies implementation (Kiteva, Gegovska-Zajkova, \& Fustik, 2008);

8. Ecological project adequacy. Lack of sense of complementary projects of SHPP with other projects (water supply, irrigation, fish farms, sawmills, mountain tourism resorts, etc.)

The potential environmental impacts associated with solar power - land use and habitat loss, water use, and the use of hazardous materials in manufacturing - can vary greatly depending on the technology, which includes two broad categories: photovoltaic (PV) solar cells or concentrating solar thermal plants (CSP);

9. Risks related to human resources. The most common risks are the frequent change of project managers or their inadequate understanding of the complex issues of the SHPP, especially because of the multidisciplinary nature of such a project. Changing Project manager during project planning phase or inappropriate project planning can influence project scope of works. As a result, project time and project cost can be increased, or project quality not satisfied;

10. Poor communication between the project participants and between the project manager and the participants (landowners, ministries, civic associations, local self-government, etc.)

11. Supply capacity bottlenecks and price volatility for PV;

12. Many new PV module manufacturers entrants result in uneven module quality across marketplaces (Michelez, et al., 2011);

13. Vandalism;

14. Operation and maintenance. For PV identified risks from historical data, are a failure of mechanical part, dirt builds up on the mirror, efficiency loss, material failure;

15. Market risk (still in developing stages in the Republic of Macedonia).

We can conclude that all the above risks depend on the investment, the distribution operator, the experience of the project manager and the impact of the hydrological and environmental aspects. Risk breakdown structure is used in the second stage, in order to organize and structure previously identified risks.

Table 2 summarize only risks with high/medium impact factor and the probability of occurrence of each individual risk.

Based on these data risks matrix is filled (Fig.2). It can be noted that only those risks that have a high and medium effect and probability of occurrence (numbered in Table 2) are distinguished. Risks colored in red have the greatest impact on the success of the project, they should be promptly reacted and given an answer to deal with them. 
Table 2. Identified risks in SHPP and PVS

\begin{tabular}{|c|c|c|}
\hline Identified risks & SHPP & PVS \\
\hline $\begin{array}{l}\text { 1. Construction site } \\
\text { properties }\end{array}$ & $\checkmark$ & $x$ \\
\hline $\begin{array}{l}\text { 2. Political involvement } \\
\text { and instability; }\end{array}$ & $\checkmark$ & $\checkmark$ \\
\hline 3. Public policy & $\checkmark$ & $\checkmark$ \\
\hline $\begin{array}{l}\text { 4. Grid connection/ delay } \\
\text { of a few months }\end{array}$ & $\checkmark$ & $\checkmark$ \\
\hline $\begin{array}{l}\text { 5. New PV module } \\
\text { manufacture }\end{array}$ & $x$ & $\checkmark$ \\
\hline $\begin{array}{l}\text { 6. Operation and } \\
\text { maintenance }\end{array}$ & $\checkmark$ & $\checkmark$ \\
\hline $\begin{array}{l}\text { 7. Extreme weather } \\
\text { conditions }\end{array}$ & $\checkmark$ & $\checkmark$ \\
\hline $\begin{array}{l}\text { 8. Right to use the land } \\
\text { for the construction }\end{array}$ & $\checkmark$ & $\checkmark$ \\
\hline 9. VAT increase & $\checkmark$ & $\checkmark$ \\
\hline $\begin{array}{l}\text { 10. Impact on the local } \\
\text { community }\end{array}$ & $\checkmark$ & $x$ \\
\hline $\begin{array}{l}\text { 11. Financial risk - cost } \\
\text { increase }\end{array}$ & $\checkmark$ & $\checkmark$ \\
\hline $\begin{array}{l}\text { 12. Natural hazards } \\
\text { (earthquake, flooding, } \\
\text { and landslide) }\end{array}$ & $\checkmark$ & $\checkmark$ \\
\hline $\begin{array}{l}\text { 13. Risks related to } \\
\text { human resources }\end{array}$ & $\checkmark$ & $\checkmark$ \\
\hline $\begin{array}{l}\text { 14. Access to } \\
\text { infrastructure (road, } \\
\text { electricity, and water) }\end{array}$ & $\checkmark$ & $x$ \\
\hline 15. Revenue (cash flow). & $\checkmark$ & $\checkmark$ \\
\hline 16. Power loss & $\checkmark$ & $\checkmark$ \\
\hline
\end{tabular}

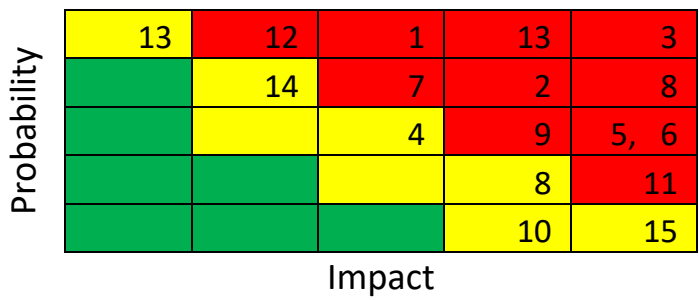

Fig.2. Risks matrix based on table 2

\section{Risk response, control, and monitoring}

Risk handling strategies should consider the main risks evaluated in qualified risk analysis. Four different strategies are considered as risk response and control:
1. Red marked risks should avoid or eliminate in order to protect project objectives from its impact.

2. Early action in designing phase can reduce the impact and/or probability of risk.

3. The negative impact of some risks identified in RES projects can be transferred to an insurance company or

4. Accepted by establishing a contingency reserve (time, money or other resources).

The application of any of these strategies depends on the project manager's decision. This means it depends on his knowledge and experience in dealing with projects of this type.

\section{CONCLUSIONS}

Due to the complexity, the dynamics of RES project during its life cycle, from establishment to its closure, should be directed towards good communication between the project manager and the subordinates for the proper coordination of the three parameters of the project management: time, quality and costs. It should be done in order to timely complete the project and delivery with the specified quality without exceeding the planned budget.

However, based on the research, it can be concluded that most often the risks are ignored or treated in a very arbitrary way, and so many of the possibilities remain unsupervised. In current practice, management is usually not oriented/ adjusted to an appropriate risk treatment. Not only for top management but for many project managers, risk management is a new work environment and as such, it is difficult to learn and manage the overall project portfolio of the company. The reason for that situation is insufficient training or lack of experience.

It should be emphasized that the application of risk management in renewable energy projects is an iterative process. This process should begin in the early phase of the project and be implemented throughout the project's economic life. For RES Projects (SHPP and PV) we recommend collecting and organizing risks, experienced in the project, into a risk database. Later, the database can be used for decision making whether a certain risk could occur and on which risks RES project could be exposed to. 


\section{WORKS CITED}

Kendrick, T. (2003). Identifying and Managing Project Risk: Essential Tools for Failure-Proofing Your Project. AMACOM.

Kiteva, N., Gegovska-Zajkova, S., \& Fustik, V. (2008). Sensitivity Analysis for Risk Assessment in Small Hydro Projects, Thematic Field: Renewable energy resources. Ohrid: International Symposium Energetics.

Michelez, J., Rossi, N., Blazquez, R., Martin, J. M., Mera, E., Christensen, D., . . Stevens, G. (2011). Risk Quantification and Risk Management in Renewable Energy Projects. Humburg, Germany: Altran GmbH \& Co.KG, EA-RETD.

PMI. (2010). A Guide to The Project Management Book of Knowledge (PMBOK Guide) - Fourth Edition. Pennsylvania, USA: Project Management Institute.

Rausand, M. (2004). System Reliability Theory: Models, Statistical Methods, and Applications. Second Edition (Hardcover).

REN21. (2017). Advancing the Global Renewable Energy Transition - Highlights of the REN21 Renewables 2017 Global Status Report in perspective. Mexico: MEXIREC, Mexico International Renewable Energy Conference.

Swider, D., Beurskens, L., Davidson, S., Twidell, J., Pyrko, J., Prueggler, W., \& Skema, R. (2008). Conditions and costs for renewables electricity grid connections: examples in Europe. Renewable Energy, 33(8), 1832-1842.

Tonchia, S. (2008). Industrial Project Management Planning. Springer-Verlag Berlin: University of Udine.

Wallnerstrom, C. (2009). Risk Management Applied to Electrical Distribution Systems. Prague, Czech Republic: IET.

Wideman, R. M. (1992). Project and Program Risk Management - Guide to Managing Project Risks and Opportunities. Pennsylvania, USA: Project Management Institute.

Wing, L. C., \& Jin, Z. (2015). Risk management methods applied to renewable and sustainable energy: A review. Journal of Electrical and Electronic Engineering, Special Issue: Sustainable and Renewable Energies and Systems, 3(1-1), 1-12. doi:10.11648/j.jeee.s.2015030101.11

Received for publication: $\quad 09.02 .2018$

Revision received: $\quad 09.08 .2018$

Accepted for publication: 27.12 .2018

\section{How to cite this article?}

Style - APA Sixth Edition:

Petrova, N., Rogleva, N. K., \& Fustik, V. (2019, January 15). Managing Renewable Energy Projects Including Risk Analysis. (Z. Čekerevac, Ed.) MEST Journal, 7(1), 71-79. doi:10.12709/mest.07.07.01.10 
Style - Chicago Sixteenth Edition:

Petrova, Natalija, Nevenka Kiteva Rogleva, and Vangel Fustik. 2019. "Managing Renewable Energy Projects Including Risk Analysis." Edited by Zoran Čekerevac. MEST Journal (MESTE) 7 (1): 71-79. doi:10.12709/mest.07.07.01.10.

Style - GOST Name Sort:

Petrova Natalija, Rogleva Nevenka Kiteva and Fustik Vangel Managing Renewable Energy Projects Including Risk Analysis [Journal] // MEST Journal / ed. Čekerevac Zoran. - Belgrade - Toronto : MESTE, January 15, 2019. - 1 : Vol. 7. - pp. 71-79. doi:10.12709/mest.07.07.01.10.

Style - Harvard Anglia:

Petrova, N., Rogleva, N. K. \& Fustik, V., 2019. Managing Renewable Energy Projects Including Risk Analysis. MEST Journal, 15 January, 7(1), pp. 71-79.

Style - ISO 690 Numerical Reference:

Managing Renewable Energy Projects Including Risk Analysis. Petrova, Natalija, Rogleva, Nevenka Kiteva and Fustik, Vangel. [ed.] Zoran Čekerevac. 1, Belgrade - Toronto : MESTE, January 15, 2019, MEST Journal, Vol. 7, pp. 71-79. 